\title{
Study at Home During the Covid-19 Pandemic as a Legal Protection for Children's Rights in Indonesia
}

\author{
Ratri Novi Erdianti ${ }^{*}$, Nur Putri Hidayah ${ }^{2}$
}

1,2 Law, Faculty of Law, University of Muhammadiyah Malang, Malang, East Java, 65144, Indonesia

*Corresponding author: ratri@umm.ac.id

\begin{tabular}{|c|c|}
\hline Article & Abstract \\
\hline $\begin{array}{l}\text { Article History } \\
\text { Received: June 13, 2020; } \\
\text { Reviewed: June 15, 2020; } \\
\text { Accepted: Sept 29, 2020; } \\
\text { Published: Sept 30, } 2020\end{array}$ & $\begin{array}{l}\text { The application of the online learning system during the COVID-19 pandemic } \\
\text { has caused problems related to learning methods that require adequate facilities } \\
\text { which not all students have them. In addition, the community also feels that this } \\
\text { method is not optimal for students, especially elementary school students who find } \\
\text { it difficult to accept online learning which also due to heaps of works to replace the } \\
\text { material students can use. The purpose of this paper is to see that the study at home } \\
\text { policy is the right government act to take in accordance with the legal protection } \\
\text { mandated by Law No. } 35 \text { of } 2014 \text { concerning Amendments to Law No. } 23 \text { of } \\
2002 \text { concerning Child Protection to continue on carrying out the learning process } \\
\text { so that the world of education is not paralyzed due to the spread of COVID-19. } \\
\text { The purpose of this study is to examine the study at home policy as a guarantee of } \\
\text { legal protection mandated by Law No. } 35 \text { of } 2014 \text { concerning Amendments to } \\
\text { Law No. } 23 \text { of } 2002 \text { concerning Child Protection. The method used in this study } \\
\text { is the normative method. The outcomes show that online learning policies are the } \\
\text { best solution and are in line with the principles of legal protection for children's } \\
\text { rights in Indonesia, especially regarding the right to be safe from harm, to be kept } \\
\text { away from disease, and the right to live and develop. }\end{array}$ \\
\hline
\end{tabular}

(C)2020; This is an Open Access Research distributed under the term of the Creative Commons Attribution License (https://Creativecommons.org/licences/by/4.0), which permits unrestricted use, distribution, and reproduction in any medium, provided the original works is properly cited.

\section{INTRODUCTION}

In recent months, countries around the world have been dealing with an ordeal, namely the spread of COVID-19. The increase in the number of COVID-19 cases occurred in a short time and needed immediate actions. The coronavirus can simply spread and infect anyone regardless of age. This virus can be transmitted simply through physical contact with sufferers. Unfortunately, there is no specific drug to treat cases of coronavirus infection until now (Mona, 2020). Hundreds of thousands of people have been infected and thousands more have died. Indonesia ranks fourth after 
Mexico, Iran, and Russia which later followed by India in the last 5 positions (Admin, 2020). In Indonesia itself, the government has given appeals to the public so that the response to this outbreak will be effective and efficient (Buana, 2020). However, in reality, there are still many Indonesian citizens who do not heed this appeal. A massive number of people around the world have become victims of death due to viruses infecting humans, so various policies are carried out by countries around the world to overcome the virus spread, including Indonesia.

Indonesia is one of the 19 co-affected countries that also has an impact on problems in various sectors of human life, starting from the economic, education, tourism, trade, and other sectors. The COVID-19 virus attacks humans regardless of age, from the age of children to the elderly are capable to be the victims of this deadly virus. As a result of the COVID-19 pandemic, several policies have been implemented to break the chain of the COVID-19 spread in Indonesia. One of the attempts made by the government in Indonesia is to apply an appeal to the public to conduct physical distancing (Muhyiddin, 2020), namely an appeal to maintain physical distances between persons, avoid activities in all forms of crowds, gatherings, and avoid meetings that involve many people. These attempts are aimed at the public to break the chain of the spread of COVID-19 pandemic that is currently emerging.

The authors' highlight is that among children who are very vulnerable in becoming victims, it is necessary to conduct protective attempts in dealing with the spread of COVID-19. The spread of the virus that spread throughout all regions in Indonesia has harmed the education sector for children as the fundamental right for every child. The existence of restrictions on interaction following the Ministry of Education and Culture of the Republic of Indonesia issued a policy under the Circular Letter No. 4 of 2020 concerning the Implementation of Education Policy in Emergency Situation of the COVID-19 Spread, by closing schools and replacing the Teaching and Learning process using an online system (e-learning). During this pandemic, in the end children have to do the learning process at home considering it is feared that if they are still going to school, there will be a higher risk of being infected by the COVID-19. Approximately nearly four months that children must undergo study at home method using the online system. All levels of education starting from Kindergarten (Muhdi \& Nurkolis, 2020), Elementary School (Dewi, 2020), Middle School (Arsendy, Sukoco, \& Purba, 2020), High School (Mustakim, 2020) to Higher Education (Zhafira et al., 2020) are forced to carry out the learning process online. In fact, due to COVID-19 both in Indonesia and globally, the government through the Circular Letter of the Ministry of Education and Culture No. 4 of 2020 announced this year's National Examination (UN) was officially abolished. Starting from the 
Elementary School (SD) level to the High School (SMA) level. The government has officially removed the National Examination (UN) for 2020.

The use of online learning system does reap both positive and negative things, considering that Indonesia's geography lies from Sabang to Merauke where the different geographical conditions appear to be one of the problems. In Indonesia, many families who are not familiar with studying at home. Homeschooling for Indonesian families is a big surprise especially for the productivity of parents who are usually busy with work outside the house (Syah, 2020), likewise with the psychological problems of students who are accustomed to learning face-to-face with their teachers. All elements of education in social life are harmed due to COVID-19 that made the teaching takes place online. This process runs on a scale that has never been measured and tested because it has never happened before.

Inevitably, remoted villages with very dense school-age populations are in confusions, because the infrastructure of information and technology is very limited (Poncojari Wahyono et al., 2020). This online learning system is a signal-constrained access to information which causes retarded access to information. Students sometimes miss information due to insufficient signal. As a result, they are late in submitting assignments given by the teacher. Changes in teaching and learning patterns will certainly never be separated from the role of teachers, especially changes in online learning patterns. Teachers must be prepared to face various learning conditions and student conditions, including the development of life within the society (Poncojari Wahyono et al., 2020). Not to mention the teacher needs to check a load of assignments that have been submitted by the students that causes gadget storage space even more limited. The application of online learning also makes educators to rethink about the learning models and methods that will be used. At first a teacher might has already prepared a learning model that will be used, but then the prepared learning model needs to be changed under certain circumstances.

In addition, as we can see, not all of the community are fully proficient in technology. Whether it is the teachers, students, and parents themselves who are still at the stage of adaptation to current technological advances, especially those who are in villages or remote areas, and people born in the 1960s. It is highly difficult to learn further, especially for teachers. There are still many teachers who not yet adept at applying current technology.

Although it reaps the negative impacts, the learning process from home is reasonable to be implemented. The government policy to conduct learning at home is issued as an attempt to protect children from being infected by the coronavirus. So 
this study at home policy is an appropriate action to take in addressing the problem faced within the education sector during this pandemic.

Basically, even though there are negative impacts, there are also many positive impacts from online learning. Educators who are able to master various online learning tools will create thoughts about more varied learning methods and models that have never been done by educators previously. For example, teachers create creative video content as teaching material. In this case, the teacher becomes more persuasive because it makes students more interested in the material provided by the teacher through creative video. Students will certainly be able to understand what is explained by the teacher through creative videos made by the teacher. So that with the application of learning models at home, students will not feel bored in participating in online learning. The use of technology in completing assignments for students can also lead to creativity among students in developing the knowledge they already have (Hidayah \& Wicaksono, 2020). With a variety of learning methods from teachers, they can create creative learning products that can develop critical thinking through their own analysis, without leaving the subject matter that has been delivered by the teacher.

The purpose of this paper is to see that the study at home policy is an appropriate government act according to the guarantee of legal protection mandated by Law No. 35 of 2014 concerning Amendment to the Law No. 23 of 2002 concerning Child Protection in continuing to carry out the learning process so that the world of education is not paralyzed due to the problems caused by the spread of COVID-19. This paper can be used as a consideration for the government to create policies about how the school learning process for children takes into account the interests and safety of the children. So that the legal aspects of child protection in Indonesia will be guaranteed.

\section{METHOD}

The method used in this research is normative legal research method (Peter Mahmud Marzuki, 2014). The method (Arliman S, 2018) used for research purposes is to analyze whether the study at home policy is the right step in protecting child law in Indonesia. The data is collected by conducting literature study according to the normative legal research methods used. The literature study is carried out to answer the problem formula which is secondary data. The secondary data used is the result of a combination of primary and secondary legal materials. The primary legal material is Law No. 35 of 2014 Jo. Law No. 23 of 2002 concerning Child Protection. Secondary legal data is the theory and opinion of experts on the concept of child protection and learning methods used online and offline. These data are qualitative in nature and is presented in the form of analysis description (Soerjono Soekanto, 2018). 


\section{RESULTS AND DISCUSSION}

Education issues are the responsibility of all parties, namely, the government (Temon Astawa, 2017) (Wiratno, 2016), educational institutions (Megawanti, 2012), teachers (Megawanti, 2012), parents (Megawanti, 2012), and the community (Temon Astawa, 2017) (Wiratno, 2016). Various attempts were made to overcome various educational problems, especially during the COVID-19 pandemic.

After the Corona Virus Disease 2019 (COVID-19) pandemic, the Indonesian Ministry of Education and Culture issued two policies, namely Circular Letter No. 3 of 2020 (Ministry of Education and Culture, 2020c) and Circular Letter No. 4 of 2020 (Ministry of Education and Culture, 2020d). These two policies issued by the Ministry of Education and Culture are related to the prevention of COVID-19 in the education sector and the implementation of educational policies during the emergency of the spread of COVID-19. The study at home policy is known as online distance learning or often called online learning. The Ministry of Religion also issued a policy regarding the learning and evaluation mechanism of madrasas during an emergency to prevent the spread of COVID-19 by utilizing e-learning platforms (Muhdi \& Nurkolis, 2020).

UNICEF, WHO, and IFRC in the Prevention and Control of COVID-19 in Schools stated that when the situation for the spread of the virus is getting faster, schools must be closed and the education process must continue through online learning activities using various media. UNESCO data states that 1.5 billion students and 63 million primary to secondary school teachers in 191 countries have been affected by the COVID-19 pandemic, something that has never happened before (Apriansyah, 2020). The world of education then was 'forced' to change the face-to-face learning method into online learning. This forced digital transformation is the safest way to stop the spread of the epidemic caused by coronavirus. Therefore, the right of students to obtain education remains a priority without neglecting mental health and safety.

The study at home policy does separate new problems from the student learning. The substantial impact experienced by students from the teaching and learning process at home is that students feel that they are constrained to do distance learning without adequate facilities and infrastructure at home. This facility is very important for a streamlined teaching and learning process. Online learning at home requires adequate basic facilities such as laptops, computers or mobile phones that will facilitate students in the online learning process. The next obstacle is the length of the student's adaptation process to undergo the distance learning process, which will have an impact on the ineffective teaching and learning process. Moreover, the fact that schools are closed for a very long period of time drives children to feel bored (Handayani, 2020). 
Children are starting to get bored for staying inside the house and having the desire to go to school so they can play with their friends, because students are accustomed to be at school to interact with their friends, play and joke around with their friends, and meet their friends and teachers in person. Moreover, students will lose their social life (Erni et al., 2020). They can play and interact with their friends at school but at this time they cannot and they also feel lonely at home with parents that creates less interaction with fellow peers, teachers, and people at school (Erni et al., 2020).

The existence of the COVID-19 outbreak forces students to use technology proficiently, they inevitably have to do the learning process remotely using technology whether they like it or not. Every school needs to prepare distance learning tools and systems as well as providing technical guidance to teachers in using modern technology in teaching to improve the student's quality in primary schools (Purwanto et al., 2020).

In addition, the use of online learning here is believed by the community to be less than optimal for students to receive learning material so that sometimes teachers replace learning materials more by giving students assignments to work on as a substitute for learning material. It is believed to be difficult for both students and parents who feel they must become teachers to accompany their children as students considering that not all of the social conditions of society have the capability to teach their children in a common way.

Apart from the study at home policy, it does have some significant negative impacts, but it also cannot be separated from the aspect of child protection. This policy was issued by the government so that children carry out the learning process at home with a lot of considerations so that it cannot be separated from the aspect of legal protection of children's rights.

The positive thing about learning from home is that social interactions within the family also determine how students behave during the learning process. There are common factors in a family situation that can have a beneficial or influential effect that hinders student learning behavior. In this state, the role of parents becomes important, which is how parents respond to the implementation of educational policies during the online learning process from home (study at home). On the other hand, children must have an awareness that what they do, especially relating to the learning process at home, is also an obligation that must be done which includes their duties. In the learning process at home, children might experience anxiety, stress, sadness, boredom, and other feelings. For children like this, the role of parents is demanded to help children have self-regulating so they are able to teach themselves in an effort to provide internal reinforcement. Once children have started to build reinforcement within 
themselves according to their learning assignments, it will have a significant impact on themselves (Subarto, 2020).

With the assistance of parents for their children, learning process that is carried out at home can simplify parents to monitor or supervise the child's learning progress directly. Parents will find it easier to guide and supervise children's learning at home. This will lead to more intensive communication and closer relationship between the child and the parents. Parents can provide direct guidance to children about learning material that children do not understand. In fact, parents are the key role in children's education development. In online learning activities provided by teachers, parents can monitor the extent of their children's competencies and abilities. Then the obscurity of the material provided by the teacher will make the communication between parents and children more intertwined. Parents can help the material difficulties faced by their children.

In addition, another positive impact for children is although it seems to be difficult for middle school students and students for lower levels of education, but this learning method is believed to be more practical for high school and university students. Moreover, this learning method must be supported by suitable classroom design and delivery mechanisms so that online learning can encourage children to reflect on their beliefs, provide a safe environment for discussing various perspectives, guide them to explore, validate, and expand new views as well as be able to support them to develop new roles.

Furthermore, in relation to the study at home policy in the perspective protecting children's legal rights, it is necessary to discuss what is the essential meaning of child protection itself. Maidin Gultom explained that child protection is all efforts made to produce a situation in which children can fulfill their rights and obligations, so that the process of child development can be carried out naturally, physically, spiritually, and socially (Gultom, 2014). Article 1 to 2 Law No. 35 of 2014 explained that child protection is all activities enforced to guarantee and protect children and their rights so that they can live, grow, develop, and participate optimally in accordance with human dignity and protection from violence and discrimination.

Meanwhile, legal protection defined by Phlipus M.Hadjon stated that what is meant by legal protection is a subjective condition which demands the necessity of a number of subjects to immediately obtain resources for the continuity of the existence of a guaranteed and protected legal subject, so that their validity is regulated in the process of political and economic decision-making, especially in the distribution of resources, both within individual and structural ranks (Prakoso, 2016). 
In relation to legal protection, the applicable law here is related to law as a system. Related to this, Lawrence Friedman stated that there are three components that influence the law as a system. Namely substance, structure, and culture. According to Friedman, the legal substance is related to laws and regulations on how an institution should behave (Friedman, 2009). Legal structure refers more to institutions than the legal system which determines whether the law is properly implemented or not. Structure is part of the legal system that operates in a mechanism (Erdianti \& Al-Fatih, 2019). Legal structure is a framework. It is a part of law that remains eternal or a part that gives a form to speak as a whole. Legal structure according to Friedman will lead to the institution in a court practice regarding the number of judges or people. Whereas according to Friedman, legal culture is an element of social attitudes and values that originate from the society. Thus the culture here refers to the attitude of the community that can be derived from the habits, views or thoughts of the community as the social control within the law in various matters that exist in the community.

Presumably, if seen from L. Friedman's opinion on the aspect of legal protection, this should be done if the components mentioned above have been implemented. Regarding the substance of the study at home policy, the government has issued a policy which in this case prohibits educational institutions from conducting the learning process during the pandemic. Structurally, school institutions, are the parties involved in implementing what is mandated by the State to comply with online learning process using various methods in accordance with procedures demanded by the State. Cultural aspects are aspects of society that support the online learning process, for example, parents facilitate the online learning and support by assisting children in online learning.

The three components above, if carried out optimally, will be the right solution for educational problems that occur during this pandemic. The new normal life condition now arises within the community during this pandemic, namely the condition of citizens returning to normal activities but still strictly paying attention to health protocols. This situation raises the question of whether the learning process will be carried out as before by going to school or not. To answer that question, it must really be paid close attention to whether the government mechanism is ready to return children straight back to school or not, given the fact that the pandemic is not over yet. Schools become an environment that must have awareness to comply with health protocols. In this group, there is a more intensive and closer social interaction, namely face-to-face group where members of this group often interact with each other directly in person and get to know each other more closely and have a close relationship. 
But presumably, we also need to rethink again about sending our children back to school given that the condition of children's immunity which is still susceptible to viruses around them (Tarigan, 2020) (Pradana et al., 2020). Although it has been equipped with health protocol guidelines that must be done while at school, it will not be an easy thing for a child to do. Parents will find it difficult to monitor healthy lifestyles if the children are at school because it is impossible for us to prevent children from conducting physical contacts while playing and having fun with their friends. So it will become parents' concern because of the ongoing pandemic situation in Indonesia. Parents are concerned that their children will catch COVID-19 if they go to school even though they have implemented health protocols that have been regulated by the government. Although the government has provided guidance for schools to facilitate adequate facilities that support these health protocols, this does not guarantee that these schools will be spared from spreading COVID-19, and this becomes a burden on parents' minds. Complying with the health protocols is not as practical as we think. Required to always wear a mask, required to frequently wash hands, and maintaining physical distance between students. Authors' analysis on this is that it is not easy to implement, especially by children.

Talking about the age of children who attend school, of course, they will be faced with various categories of children and whether they will comply with health protocols. High school students may already understand the importance of health protocols that must be followed when they study at school or college, but not for children at an early stage of age namely kindergarten or elementary school students. Therefore, based on our analysis, it is quite difficult to implement, because younger children may not understand the practice of health protocols well enough. Even though parents at home have already given them the reminder to maintain their physical distance, put on a mask, and frequently wash their hands, there is no guarantee that they will strictly implement that at school. It is a dilemma for us to implement school entry policy when this pandemic has not ended in Indonesia, considering that parents cannot directly monitor their children continuously in always being careful and pay attention to the cleanliness of their children and always maintain physical distance while socializing with their friends.

In terms of child protection, it is necessary to review the school entry policy for students, bearing in mind that it is the government's obligation to protect and keep children away from unsafe and harmful conditions when they have to return to school. Must still refer to the Child Protection Law which contains the principle of survival for children and the principle of the best interests of children. In addition, the government must also be able to ensure that every school will meet the standardized health protocols that can prevent students from being contracting COVID-19 by 
maintaining physical distance between students in schools, adequate health facilities, and suitable learning processes that meets children's conditions. Hopefully this school re-entry policy will consider several changes, especially for children who are not able to protect themselves from the coronavirus while at school by always implementing health protocols regulated by the government. Therefore, it is expected that the school admission policy cannot be implemented in the current condition, considering that there are more possibilities for negative things to emerge than positive things. May the government really have to guarantee the safety of children when they have to go back to school without any thrills concerned by the community who will possibly be infected with COVID-19.

Law No. 35 of 2014 concerning Amendment to Law No. 23 of 2002 concerning Child Protection stated that every child has the right to get distinctive protection, which is a form of protection received by the Child in certain situations and conditions to guarantee a sense of security from threats that endanger themselves and the lives in their growth and development. From certain conditions, it can be interpreted that conditions that threaten the safety and health are harmful to children so that if during the COVID-19 pandemic these children still need to return back to school, this will be the contrary to the special protection aspects regulated under the Child Protection Law.

After the COVID-19 pandemic entered Indonesia last mid-March 2020, to suppress the number of COVID-19 sufferers, the provincial and regional governments have issued a policy in the world of education, namely temporarily canceling face-toface learning which then substituted with online learning for all education levels. The higher institutions then manifested a system called an electronic university (eUniversity). The development of e-University aims to support the implementation of online education platform, so that universities can provide better information services to the public through the internet. Other educational services that can be carried out through the internet are by providing online course materials that can be accessed by anyone who needs them (Lestari, 2020).

In addition, this study at home policy is in line with the principles contained in the Convention on the Rights of the Child which have been adopted into Child Protection Law. Namely the principle of the best interests of child and the principles of the right to life, survival and growth, and development.

In the principle of the Principle of Best Interest for Children, all forms of protection for children should aim for the best interests of the child. This principle is listed in Article 3 paragraph (1) of the CRC "In all actions involving children carried out by governmental or private social welfare institutions, judicial institutions, 
government agencies or legislative bodies, the best interests of the child must be a primary consideration" .

This principle reminds all child protection administrators that considerations in decision making concern the child's future, not based on adult standards, let alone centering on the interests of adults. What is good in terms of adult standard is not necessarily good according to parameter of children's interests. It could be that the adult's intention is to provide help and assistance, but what actually happens is the destruction of the child's future (Jamil, 2013).

That principle states that the best interests of children must be the main consideration in all actions involving children (Haris \& Al-Fatih, 2020). This principle stipulates that the actions of interested parties are related to both the family and public or private institutions that seek to improve the social welfare of a child.

Thus the policy of online learning from home is basically very harmonious when linked to these principles. Because in this case, the best interests of a child during the COVID-19 pandemic are safety condition that still concerned to their learning processes. So that educational process even with all its shortcomings through the learning process at home but basically in accordance with the principle of the best interests of children needs to be done.

Another principle of protection that is in line with the study at home policy is the Principle of the Right to Life, Survival and Development. This principle is contained in Article 6 of the CRC paragraph (1): "States parties recognize that every child has a proficient right to life". Paragraph (2): "States parties will guarantee to the maximum extent survival and development of children ".

The mandate of this principle is highly evident that the state must ensure that every child will be guaranteed their survival because the right to live is something that is proficient within them, not a gift from the state or individuals. To guarantee the right to live means that the state must provide a conducive environment, adequate living facilities and infrastructure, as well as access for every child to obtain their basic needs. Health, security, and child safety are prioritized in this case so that the study at home policy will certainly be in line with the principles mentioned above.

\section{CONCLUSION}

The learning process through online system is the right government act regulated by the government in overcoming the educational issues during the current COVID19 pandemic. Despite the positive and negative impacts, this online system policy is 
still the most prudent solution in line with the principle of legal protection to children's rights in Indonesia, notably regarding the right to be safe from danger and kept away from diseases as well as the rights on survival and growth and development. Returning children back to school may not be feasible given the COVID-19 pandemic is alarming dangerous to the community, especially children.

\section{REFERENCES}

Admin. (2020). Indonesia Empat Besar Angka Kematian Covid-19. Jurnal Inspirasi, 1.

Apriansyah, A. (2020). Transformasi Pendidikan dan Berbagai Problemnya. LIPI Pusat Penelitian Kependudukan.

Arliman S, L. (2018). Peranan Metodologi Penelitian Hukum di Dalam

Perkembangan Ilmu Hukum di Indonesia. Soumatera Law Review, 1(1), 112-132. https://doi.org/10.22216/soumlaw.v1i1.3346

Buana, D. R. (2020). Analisis Perilaku Masyarakat Indonesia dalam Menghadapi Pandemi Virus Corona (Covid-19) dan Kiat Menjaga Kesejahteraan Jiwa. SALAM;Jurnal Sosial Budaya \&Syar'i FSH Syarif Hidayabtullah, 1(1), 217-226.

Dewi, W. A. (2020). Dampak COVID-19 terhadap Implementasi Pembelajaran Daring di Sekolah Dasar. Edukatif: Jurnal Ilmu Pendidikan, 2(1), 55-61.

Erdianti, R. N., \& Al-Fatih, S. (2019). Mewujudkan Desa Layak Anak sebagai Bentuk Perlindungan Hukum terhadap Anak di Indonesia. Justisia Jurnal Hukum, 3(2), 305-318.

Erni, S., Vebrianto, R., \& Miski, C. R. (2020). Refleksi Proses Pembelajaran Guru MTs dimasa Pendemi Covid 19 di Pekanbaru : Dampak dan Solusi. Journal of Education and Learning, 1(1), 1-10.

Friedmen, L. (2009). Sistem Hukum (Perspektif Ilmu Sosial). Nusa Media.

Gultom, M. (2014). Perlindungan Hukum Terbadap Anak dalam Sistem Peradilan Pidana Anak Di Indonesia. Refika Aditama.

Handayani, P. (2020). Penerapan Model Pembelajaran Group Investigation untuk Meningkatkan Hasil Belajar Siswa Kelas IX A SMPN 5 Kota Kediri pada Pelajaran Bahasa Indonesia Materi Teks Tantangan di Semester 1 Tahun Pelajaran 2016/2017. Jurnal Pendidikan \& Budaya WARTA PENDIDIKAN, 43(1), 4-12.

Haris, \& Al-Fatih, S. (2020). School of Intuition as An Education for Child to Prevent Corruption in Indonesia. TEST Engineering \& Management, 83, 1188411892.

Hidayah, N. P., \& Wicaksono, G. W. (2020). Legal Knowledge Management System on Family Law. Jurnal Hukum Novelty, 11(1), 68-85.

Jamil, N. (2013). Anak Bukan Untuk Di Hukum. Sinar Grafika. 
Lestari, Y. P. (2020). Dampak Positif Pembelajaran Online Dalam Sistem Pendidikan Indonesia Pasca Pandemi Covid-19. AD ALAH, Buletin Hukum Dan Keadilan, 1(1), 49-56.

MEGAWANTI, P. (2012). Meretas Permasalahan Pendidikan Di Indonesia. Formatif, 2(3), 227-234. https://doi.org/10.30998/formatif.v2i3.105

Mona, N. (2020). Konsep Isolasi Dalam Jaringan Sosial Untuk Meminimalisasi Efek Contagious ( Kasus Penyebaran Virus Corona Di Indonesia). Jurnal Sosial Humaniora Terapan, 2(2), 117-125.

Muhdi, \& Nurkolis. (2020). Keefektivan Kebijakan E-Learning berbasis Sosial Media pada PAUD di Masa Pandemi COVID-19. Jurnal Obsesi: Jurnal Pendidikan Anak Usia Dini, 5(1), 212-228.

Muhyiddin. (2020). New Normal dan Perencanaan Pembangunan di Indonesia. The Indonesian Journal of Development Planning, 4(2), 240-252.

Mustakim. (2020). The effectiveness of E-Learning Using Online Media During The COVID-19 Pandemic in Mathematics. Al Asma: Journal of Islamic Education, 2(1), $1-12$.

Peter Mahmud Marzuki. (2014). Penelitian Hukum. Kencana Prenada Media Group.

Poncojari Wahyono, Husamah, H., \& Budi, A. S. (2020). Guru profesional di masa pandemi COVID-19: Review implementasi, tantangan, dan solusi pembelajaran daring. Jurnal Pendidikan Profesi Guru, 1(1), 51-65.

Pradana, A. A., Casman, \& Nur'aini. (2020). Pengaruh Kebijakan Social Distancing Pada Wabah Covid-19 Terhadap Kelompok Rentan Di Indonesia. Jurnal Kebijakan Kesehatan Indonesia, 9(1), 34-39.

Prakoso, A. (2016). Penemuan Hukum: Sitem, Metode, Aliran dan Prosedur Dalam Menemukan Hukum.

Purwanto, A., Pramono, R., Asbari, M., Santoso, P. B., Wijayanti, L. M., Hyun, C. C., \& Putri, R. S. (2020). Studi Eksploratif Dampak Pandemi COVID-19 Terhadap Proses Pembelajaran Online diSekolah Dasar. Edupsycouns Journal, 1(1), 1-12.

Soerjono Soekanto. (2018). Penelitian Hukum Normatif: Suatu Tinjauan Singkat. In Rajawali Press. Rajawali Press.

Subarto. (2020). Momentum Keluarga Mengembangkan Kemampuan Belajar Peserta Didik Di Tengah Wabah Pandemi Covid-19. ADALAH: Buletin Hukum Dan Keadilan, 3(1), 13-18.

Syah, R. H. (2020). Dampak Covid-19 pada Pendidikan di Indonesia: Sekolah, Keterampilan, dan Proses Pembelajaran. SALAM: Jurnal Sosial Dan Budaya SyarI, 7(5), 395-402. https://doi.org/10.15408/sjsbs.v7i5.15314

Tarigan, A. P. (2020). Penyakit Menular dan Virus Corona. 
Temon Astawa, I. N. (2017). Memahami Peran Masyarakat Dan Pemerintah Dalam Kemajuan Mutu Pendidikan Di Indonesia. Jurnal Penjaminan Mutu, 3(2), 197. https://doi.org/10.25078/jpm.v3i2.200

Wiratno, B. (2016). Partisipasi Masyarakat Dalam Pendidikan. Journal Pendidikan Ilmu Sosial, 26(14), 28-34. https://doi.org/10.18592/ittihad.v14i26.874

Zhafira, N. H., Ertika, Y., \& Chairiyaton. (2020). Persepsi Mahasiswa terhadap Perkuliahan Daring sebagai Sarana Pembelajaran selama Masa Karantina COVID-19. Jurnal Bisnis Dan Kajian Strategis Manajemen, 4(1), 37-45. 